\title{
PERLINDUNGAN HUKUM BAGI PENGHUNI SATUAN RUMAH SUSUN DIBIDANG PENGELOLAAN RUMAH SUSUN DI BANDUNG DIHUBUNGKAN DENGAN UNDANG-UNDANG NOMOR 20 TAHUN 2011 TENTANG RUMAH SUSUN
}

\author{
Hj. Ina Budhiarti Supyan \\ Sekolah Tinggi Hukum Bandung \\ E-mail: inabudhiarti@ymail.com
}

\begin{abstract}
Flat development in Indonesia is based on Act No. 20 year 2011 on Flat. This Act obliges the flat developer to make a flat residents association when the flat has been occupied by the residents. This should be carried out and performed bu the developer together with the resients. It means that every flat development is obliged to make an association for flat residents (PPSRS) which has legal entities. The research has found a problem that there should be a protection for flat residents in the field of flat management. Besides, There are shopping centers built, developed which is based on Act No. 20 year 2011 on Flat, and have been been standing for along time, but they do not have associations which have legal entities.
\end{abstract}

Keywords: law protection; flat residents; associationt

\begin{abstract}
Abstrak
Pembangunan rumah susun di Indonesia didasarkan pada Undang-Undang Nomor 20 Tahun 2011 tentang Rumah Susun, undang-undang tersebut mewajibkan juga apabila satuan rumah susun telah memiliki penghuni atau telah dihuni diwajibkan untuk membentuk perhimpunan penghuni rumah susun. Kewajiban tersebut wajib dilaksanakan oleh penghuni dan oleh penyelenggara pembangunan, yang artinya setiap pembangunan satuan rumah susun wajib membentuk Perhimpunan Penghuni Satuan Rumah Susun (PPSRS) yang berbadan hukum. Peneliti menemukan permasalahan bahwa diperlukannya perlindungan hukum bagi penghuni satuan rumah susun dalam bidang pengelolaan rumah susun, terdapat pusat perbelanjaan yang didirikan berdasarkan Undang-Undang Nomor 20 Tahun 2011 tentang Rumah Susun yang berbentuk satuan rumah susun, telah berdiri lama dan membentuk satuan rumah susun, tetapi belum juga membentuk perhimpunan yang berbadan hukum.
\end{abstract}

Kata Kunci: Perlindungan Hukum, Rumah Susun, Asosiasi. 


\section{A. PENDAHULUAN}

Pemerintah menganggap perlu mengembangkan konsep pembangunan perumahan yang dapat dihuni bersama di dalam suatu gedung bertingkat, dalam satuan-satuannya dapat dimiliki secara terpisah yang dibangun baik secara horizontal maupun secara vertikal. Pembangunan perumahan yang demikian itu sesuai dengan kebutuhan masyarakat kita ini, terutama masyarakat perkotaan dengan mempergunakan sistem condominium.

Condominium merujuk kepada konsep kepemilikan, sedangkan apartemen dan flat merujuk kepada fisik bangunannya. Kita juga sering mendengar istilah Strata Title, yaitu terminologi barat popular tentang suatu kepemilikan terhadap sebagian ruang dalam suatu gedung bertingkat seperti apartemen.

Strata title dijelaskan secara jelas sebagai hak milik atas satuan rumah susun. Dijelaskan pula bahwa sebagai pemegang hak, seseorang berhak pula atas sebagian proporsi bagian bersama, benda bersama maupun tanah bersama. Hak kepemilikan atas bagian bersama, benda bersama maupun tanah bersama tidak menunjuk kepada bagian atau lokasi tertentu tetapi dalam bentuk proporsi atau prosentase kepemilikan. Kesimpulannya bahwa strata title merujuk kepada pemisahan akan hak seseorang terhadap beberapa strata atau tingkatan.

Pembangunan rumah susun di Indonesia didasarkan pada UndangUndang No. 20 Tahun 2011 tentang Rumah Susun, undang-undang tersebut mewajibkan juga apabila satuan rumah susun telah memiliki penghuni atau telah dihuni diwajibkan untuk membentuk perhimpunan penghuni rumah susun. Kewajiban tersebut wajib dilaksanakan oleh penghuni dan oleh penyelenggara pembangunan, yang artinya setiap pembangunan satuan rumah susun wajib membentuk Perhimpunan Penghuni Satuan Rumah Susun (PPSRS) yang berbadan hukum.

Berdasarkan Latar Belakang Masalah di atas, maka dapat diidentifikasikan masalahnya sebagai berikut:

1. Apakah yang menjadi ketentuan dasar bagi perlindungan hukum penghuni satuan rumah susun dibidang pengelolaan di Bandung?

2. Bagaimanakah perlindungan hukum bagi penghuni satuan rumah susun di bidang pengelolaan rumah susun ditinjau dari peraturan yang berkaitan di wilayah Kota Bandung dan apakah kendala-kendalanya?

\section{B. PEMBAHASAN}

Indonesia sebagainegarahukum segala sesuatu tindakan atau perbuatan harus didasarkan pada hukum yang berlaku. Hukum diterapkan salah satu tujuannya adalah agar memperoleh kepastian hukum bagi para pihak. Hal ini pada teori yang dikemukakan oleh Van Kan. Van Kan yang berpendapat tujuan hukum adalah untuk menjamin kepastian hukum dalam pergaulan masyarakat ${ }^{1}$. Menurut Van Apeldoorn, hukum memiliki tujuan untuk mengatur tata tertib masyarakat secara

1 Achmad Rustandi, Ibrahim Bachtiar, Pengantar Teori Hukum, Multi Karya Ilmu, Bandung, 1983, hlm. 19. 
adil, dan damai². Hukum juga hendaknya memperhatikan teori yang dikemukakan oleh Prof. Dr. Mochtar Kusumaatmaja, S.H., yaitu bahwa hukum adalah sebagai sarana pembaharuan masyarakat ${ }^{3}$.

Indonesia sebagai negara hukum harus juga memperhatikan darar pembentukan hukum berupa Undang-Undang Dasar 1945. Berdasarkan Amandemen UndangUndang Dasar 1945 Pasal 28 H:

1. Setiap orang berhak hidup sejahtera lahir dan batin, bertempat tinggal, dan mendapatkan lingkungan hidup baik dan sehat serta berhak memperoleh pelayanan kesehatan.

2. Setiap orang mendapat kemudahan dan perlakuan khusus untuk memperoleh kesempatan dan manfaat yang sama guna mencapai persamaan dan keadilan.

3. Setiap orang berhak atas jaminan sosial yang memungkinkan pengembangan dirinya secara utuh sebagai manusia yang bermartabat.

4. Setiap orang berhak mempunyai hak milik pribadi dan hak milik tersebut tidak boleh diambil alih secara sewenang-wenang oleh siapa pun.

Berdasarkan kesimpulan pasal di atas, maka rakyat Indonesia memiliki hak, antara lain:

1 Hak untuk hidup sejahtera lahir dan batin;

2. Hak bertempat tinggal; dan

3. Hak untuk mendapatkan lingkungan hidup baik dan sehat serta berhak memperoleh pelayanan kesehatan.
4. Pemenuhan hak tersebut dibentuk terlebih dahulu dasar hukumnya, yaitu dengan diterbitkannya UndangUndang Nomor 20 Tahun 2011 tentang Rumah Susun (UU Rusun). Undangundang ini menggantikan Undangundang yang telah lalu, yaitu UndangUndang Nomor 16 Tahun 1985 tentang Rumah Susun dan Peraturan Pelaksanaan Undang-Undang Nomor 16 Tahun 1985 berupa Peraturan Pemerintah (PP) Nomor 4 Tahun 1988 tentang Rumah Susun.

5. Rumah susun merupakan model perumahan yang baru di Indonesia. Zaman dahulu Indonesia mengenal tiga pola sistem pengadaan perumahan kota, antara lain:

“a. Perumahan yang dibangun oleh pihak swasta, bermutu baik, mahal dan diperuntukkan penduduk yang berpenghasilan tinggi, utamanya untuk kalangan Eropa dan Timur Asing.

b. Perumahan yang pengadaannya untuk dipakai sendiri, baik pribadi maupun oleh badan usaha. Termasuk di dalamnya adalah perumahan-perumahan pegawai negeri, karyawan swasta, dan lainlain.

c. Perumahan kampung. Perumahan di kampung adalah perumahan masyarakat pribumi yang jumlahnya mencapai dua pertiga rumah yang ada."4

\section{Ibid.}

Ibid., hlm. 20.

Adrian Sutedi, Hukum Rumah Susun \& Apartemen, Sinar Grafika, Jakarta, 2012, hlm. 2. 
Kepemilikan satuan rumah susun pada saat sekarang ini apabila terjadi jual beli harus dilakukan dihadapan Pejabat Pembuat Akta Tanah (PPAT).

"Karena pemindahan hak tersebut merupakan perbuatan hukum yang sifatnya tunai, maka hak milik atas satuan rumah susun yang bersangkutan berpindah kepada pihak pembeli pada saat selesai dibuat akta jual beli oleh PPAT."5

Pendirian rumah susun yang didasarkan pada UU No. 20 Tahun 2011 merupakan aturan yang terbaru yang menggantikan UU No. 16 Tahun 1981. Terbitnya UU No. 20 Tahun 2011 tidak disertai dengan perubahan pada aturan pelaksannya, antara lain peraturan pemerintah. Tidak adanya aturan pemerintah ini memungkinkan timbulnya perbedaan presepsi di tingkat daerah. Sebaiknya perubahan undang-undang disertai dengan pembentukan peraturan pelaksanaannya.

Peraturan dibidang rumah susun sekarang ini yang berlaku antara lain:

1. UU NO 20 Tahun 2011 tentang Rumah Susun.

2. Peraturan Pemerintah Nomor 4 Tahun 1988 tentang Rumah Susun.

3. Keputusan Menteri Negara Perumahan Rakyat Nomor: 06/KPTS/ BKP4N/1995 tentang Pedoman Pembuatan Akta Pendirian, Anggaran Dasar dan Anggaran Rumah Tangga Perhimpunan Penghuni Rumah Susun.
4. Peraturan Menteri Negara Perumahan Rakyat Nomor 15/PERMEN/M/2007 Tentang Tata Laksana Pembentukan Perhimpunan Penghuni Rumah Susun Sederhana Milik.

5. Disamping itu juga berlaku Kitab Undang-Undang Hukum Perdata (KUH Perdata) berkaitan dengan perjanjinan yang dibuat.

6. UU No 8 Tahun 1999 tentang Perlindungan Konsumen.

Pembangunan rumah susun di Indonesia dibangun untuk kemudian dipasarkan kepada warga. Pemasaran yang dilakukan dengan memperhatikan peraturan lain yang berkaitan dengan transaksi tersebut. Disamping peraturan yang telah disebut di atas beberapa aturan lain diantranya adalah berkaitan dengan hak atas tanah maka yang perlu diperhatikan adalah Undang-Undang No 5 Tahun 1960 tentang Peraturan Dasar Pokok-pokok Agraria, Peraturan Pemerintah No 24 Tahun 1997 tentang Pendaftaran Tanah.

Berdasarkan penggunaanya, rumah susun kemudian dapat dikelompokan menjadi:

1. Rumah susun hunian, yaitu rumah susun yang seluruhnya berfungsi sebagai tempat tinggal.

2. Rumah susun non hunian, yaitu rumah susun yang seluruhnya berfungsi sebagai tempat usaha atau kegiatan sosial.

3. Rumah susun campuran, yaitu merupakan rumah susun yang sebagian berfungsi sebagai tempat

5 Boedi Harsono, Berbagi Masalah Hukum Bersangkutan dengan Rumah Susun dan Pemilikan Satuan Rumah Susun, Majalah Hukum dan Pembangunan Desember 1986, hlm. 620. 
tinggal dan sebagian lagi berfungsi sebagai tempat usaha. ${ }^{6}$

Di Indonesia Pembangunan rumah susun memilik asas-asas yang di landasi pada Undang-Undang Nomor 20 Tahun 2011 tentang Rumah Susun. Namun sebelum diperbaharui adanya UndangUndang Nomor 20 Tahun 2011 tentang Rusun, pembangunan rumah susun di Indonesia di landasi pada Undang-Undang Nomor 16 Tahun 1985 dan ketentuan ini terdapat dalam Pasal 2 yang hanya memiliki 3 asas, yaitu:

1. Asas kesejahteraan umum,

2. Asas keadilan dan pemerataan, serta

3. Asas keserasian dan keseimbangan dalam peri kehidupan.

Sedangkan pada Undang-Undang Nomor 20 Tahun 2011 tentang Rusun, asasnya lebih banyak dibandingkan dengan Undang-Undang Nomor 16 Tahun 1985 tentang Rusun. Dalam Pasal 2 Undang-Undang Nomor 20 Tahun 2011 tentang Rusun memiliki 13 asas, yaitu:

1. Asas kesejahteraan

Asas kesejahteraan adalah kondisi terpenuhinya kebutuhan rumah susun yang layak bagi masyarakat agar mampu mengembangkan diri sehingga dapat melaksanakan fungsi sosialnya.

2. Asas keadilan dan pemerataan

Asas keadilan dan pemerataan adalah memberikan hasil pembangunan di bidang rumah susun agar dapat dinikmati secara proporsional dan merata bagi seluruh rakyat.
3. Asas kenasionalan

Asas kenasionalan adalah memberikan landasan agar kepemilikan sarusun dimanfaatkan sebesar-besarnya untuk kepentingan nasional.

4. Asas keterjangkauan dan kemudahan Asas keterjangkauan dan kemudahan adalah memberikan landasan agar hasil pembangunan rumah susun dapat dijangkau oleh seluruh lapisan masyarakat, serta mendorong terciptanya lkim kondusif dengan memberikan kemudahan bagi masyarakat berpenghasilan rendah.

5. Asas keefisienan dan kemanfaatan Asas keefisienan dan kemanfaatan adalah memberikan landasan penyelengaraan rumah susun yang dilakukan dengan memaksimalkan potensi sumber daya tanah, teknologi rancang bangun, dan industri bahan bangunan yang sehat serta memberikan kemanfaatan sebesarbesarnya bagi kesejahteraan rakyat.

6. Asas kemandirian dan kebersamaan Asas kemandirian dan kebersamaan adalah memberikan landasan penyelenggaraan rumah susun bertumpu pada prakarsa, swadaya, dan peran serta masyarakat sehingga mampu membangun kepercayaan, kemampuan, dan kekuatan sendiri serta terciptanya kerja sama antar pemangku kepentingan.

7. Asas kemitraan

Asas kemitraan adalah memberikan landasan agar penyelenggaraan rumah susun dilakukan oleh pemerintah dan

6 Imam Koeswahyono, Hukum Rumah Susun: Suatu Bekal Pengantar Pemahaman, Bayumedia, Malang, 2004, hlm. 13-14. 
pemerintah daerah dengan melibatkan pelaku usaha dan masyarakat dengan prinsip saling mendukung.

8. Asas keserasian dan keseimbangan Asas keserasian dan keseimbangan adalah memberikan landasan agar penyelenggaraan rumah susun dilakukan dengan mewujudkan keserasian dan keseimbangan pola pemanfaatan ruang.

9. Asas keterpaduan

Asas keterpaduan adalah memberikan landasan agar rumah susun diselenggarakan secara terpadu dalam hal kebijakan dan perencanaan, pelaksanaan, pemanfaatan, dan pengendalian.

10. Asas kesehatan

Asas kesehatan adalah memberikan landasan agar pembangunan rumah susun memenuhi standar rumah sehat, syarat kesehatan lingkungan, dan perilaku hidup sehat.

11. Asas kelestarian dan keberlanjutan Asas kelestarian dan keberlanjutan adalah memberikan landasan agar rumah susun diselenggarakan dengan menjaga keseimbangan lingkungan hidup dan menyesuaikan dengan kebutuhan yang terus meningkat sejalan dengan laju pertumbuhan penduduk dan keterbatasan lahan.

12. Asas keselamatan, kenyamanan, dan kemudahan

Asas keselamatan, kenyamanan, dan kemudahan adalah memberikan landasan agar bangunan rumah susun memenuhi persyaratan keselamatan, yaitu kemampuan bangunan rumah susun mendukung beban muatan, pengamanan bahaya kebakaran, dan bahaya petir; persyaratan kenyamanan ruang dan gerak antar ruang, pengkondisian udara, pandangan, getaran, dan kebisingan; serta persyaratan kemudahan hubungan ke, dari, dan dalam bangunan, kelengkapan prasarana, dan sarana rumah susun termasuk fasilitas dan aksesibilitas bagi penyandang cacat dan lanjut usia.

13. Asas keselamatan, kenyamanan, dan kemudahan

Asas keselamatan, kenyamanan, dan kemudahan adalah memberikan landasan agar pengelolaan dan pemnfaatan rumah susun dapat menjamin bangunan, lingkungan, dan penghuni dari segala gangguan dan ancaman keamanan; ketertiban dalam melaksanakan kehidupan bertempat tinggal dan kehidupan sosialnya; serta keteraturan dalam pemenuhan ketentuan administratif.

Pada Undang-Undang Nomor 20 Tahun 2011 tentang Rusun juga memuat tentang tujuan didirikannya rumah susun. Dalam UU Rusun Pasal 3 didirikannya rumah susun bertujuan untuk:

1. Menjamin terwujudnya rumah susun yang layak huni dan terjangkau dalam lingkungan yang sehat, aman, harmonis, dan berkelanjutan serta menciptakan pemukiman yang terpadu guna membangun ketahanan ekonomi, sosial, dan budaya.

2. Meningkatkan efisiensi dan evektifitas pemanfaatan ruang dan tanah, serta menyediakan ruang terbuka hijau di kawasan perkotaan dalam menciptakan kawasan permukiman yang terlengkap serta serasi dan 
seimbang dengan memperhatikan prinsip pembangunan berkelanjutan dan berwawasan lingkungan.

3. Mengurangi luasan dan mencegah timbulnya perumahan dan permukiman kumuh.

4. Mengarahkan perkembangan kawasan perkotaan yang serasi, seimbang, efisien, dan produktif.

5. Memenuhi kebutuhan sosial dan ekonomi yang menunjang kehidupan penghuni dan masyarakat dengan tetap mengutamakan tujuan pemenuhan kebutuhan perumahan dan pemukiman yang layak, terutama bagi masyarakat berpenghasilan rendah.

6. Memberdayakan para pemangku kepentingan di bidang pembangunan rumah susun.

7. Menjamin terpenuhinya kebutuhan rumah susun yang layak dan terjangkau, terutama bagi masyarakat berpenghasilan rendah lingkungan yang sehat, aman, harmonis, dan berkelanjutan dalam suatu sistem tata kelola perumahan dan pemukiman yang terpadu.

8. Memberikan kepastian hukum dalam penyediaan, kepenghunian, pengelolaan, dan kepemilikan rumah susun.

Konsumen rumah susun terutama dalam haliniadalah rumah susunkomersial di Bandung, perlu memperhatikan beberapa hal dalam memperoleh rumah susun. Rumah susun yang dibangun oleh pelaku usaha/pelaku pembangunan dapat diperoleh dengan transaksi jul beli atau dengan cara lain yaitu dengan pengikatan jual beli terlebih dahulu.
UU No 20 Tahun 2011 mengatur tentang pemasaran rumah susun. Pemasaran tersebut dapat dilakukan sebelum pembangunan sarusun dilaksanakan, apabila hal ini dilakukan sekurang-kurangnya pengembang harus sudah memiliki:

1. Kepastian peruntukan ruang.

2. Kepastian hak atas tanah.

3. Kepastian status penguasaan rumah susun.

4. Perizinan pembangunan rumah susun.

5. Jaminan atas pembangunan rumah susun dari lembaga penjamin.

Pemasaran yang dilaksanakan dalaha pembangunan belum dilaksanakan, maka harus melalui perjanjian pengikatan jual beli ( PPJB) yang dibuat dihadapan pejabat yang berwenang yaitu Notaris. PPJB memuat kepastian mengenai:

1. Status kepemilikan tanah.

2. Kepemilikan IMB.

3. Ketersediaan prasarana, sarana, dan utilitas umum.

4. Keterbangunan paling sedikit $20 \%$ (dua puluh persen).

5. Hal yang diperjanjikan.

Terhadap pembangunan rumah susun yang telah dilaksanakan, maka dapat dilaksanakan ditandai dengan adanya sertifikat laik fungsi dan sertifikat hak milik satuan rumah susun dan sertifikat kepemilikan bangunan gedung satuan rumah susun. Rumah susun komersial penguasaannya dapat dimiliki dengan jual beli atau sewa.

Penguasaan baik rumah susun sederhan dan rumah susu komersial harus dilakukan dengan pembuatan aktaakta yang dibuat dihadapan pejabat yang berwenang baik itu Notaris atau Pejabat 
Pembuat Akta Tanah (PPAT) perjanjian yang dibuat juga harus didaftarkan pada Perhimpunan Pemilik dan Penghuni Satuan Rumah Susun (PPPSRS).

Pada kasus MIM (bab III) pada penelitian ini perjanjian yang dibuat antara pihak konsumen dan pihak pelaku usaha ditanda tangani pada thun 2005. Yang artinya pada saat itu UU No 20 Tahi 2011 belum berlaku. Pada saat itu yang masih berlaku adalah UU NO 16 Tahun 1985. Perjanjian dengan Nomor akta 0103MTC-M/00VIII/05 dibuat tidak dihadapat pejabat yang berwenang hal ini disebabkan karena tidak disyarakat oleh peraturan pada saat itu. Sehingga hanya dibuat di bawh tangan saja. Perjajian Nomor akta 0103MTC-M/00VIII/05 dibuat karena terdapatnya pembayaran secara mengaangsur. Setelah angsuran terbayar lunas, maka diwajibkan membuat akta perjanjian jual beli yang harus dibuat dihadapan PPAT.

Perjanjian yang dibuat antara konsumen dan pelaku usaha harus pula di dasrkan pada KUH Pdt. Pada KUH Pdt kita akan mengenal mengenai perjajian yang merupakan salah satu sumber perikatan yang timbul serta syarat sahnya perjanjian yang terdapat pada Pasal 1320 KUH Pdt. Perjanjian Nomor akta 0103MTCM/00VIII/05 menyepakatai beberapa hak dan kewajiban yang terdapat pada para pihak termasuk juga pembentukan PPPSRS.

Pada saat ini pada objek penelitian yang terdapat bab III telah sertifikikat satuan rumah susun dan berdasarkan UU No 20 Tahun 2011, maka MIM seharusnya telah memiliki PPPSRS. Hal ini didasarkan pada Pasal 74 (1) yang memeberikan kewajiban untuk mendirikan PPPSRS yang telah berbadan hukun. Pembentukan PPPSRS ini difasilitasi oleh pelaku pembangunan/pelaku usaha. Sebelum terbentuknya PPPSRS oleh UU No 20 Tahun 2011 pelaku pembangunan/pelaku usaha wajib megelola rumah susun sebagai masa transisi. Masa transisi tersebut hanya berlaku sampai satu tahun sejak penyerahan pertamakali sartuan rumah susun kepada pemilik.

Pembentukan satuan rumah susun secara definitif belum juga terlaksanakan. Hal ini bukan berarti tanpa usah tetapi terkendala dengan beberapa faktor. Dengan di undangkannya UU No 20 Tahun 2011 seharusnya telah terhitung dalam jangka satu tahun telah terbentuk PPPSRS yang definitif.

Kendala pembentukkan PPPSRS btersebut ternyata terdapat beberapa kendala diantaranya belum terbentuknya peraturan pelaksana dari UU No. 20 Tahun 2011. Diantaranya peraturan berbentuk Peraturan Pemerintah (PP), PP yang ada sekarang ini adalah PP yang masih didasarkan peraturan yang lama yaitu UU No. 16 Tahun 1985. Khususnya di Bandung, Kota Bandung belum juga memiliki peraturan walikota berkaitan dengan PPPSRS. Peraturan walikota ini penting untuk memberikan kepastian hukum bagi warga Bandung dalam membentuk PPSRS. Hukum sebagai saran pembaharu masyarakat hendaknya berada selangkah lebih maju kedepan sehingga masayarakat memiliki kepastian hukum. Saat ini warga Bandung belum memiliki pendoman yang terbaru dalam pembentukan PPPSRS.

Pembentukan PPPSRS harus juga difasilitasi oleh pelaku pembangunan/ 
pelaku usaha berdasarkan UU No. 20 Tahun 2011, tetapi undang-undang ini juga tidak memberikan penjelasan fasilitas yang dimaksud. Dalalm undang-undang ini saja tidak menjelaskan lebih terperinci apalagi penjelasan pada peraturan pelaksanannya.

Pembentukan PPPSRS ini juga bila dikaitkan dengan KUH Perdata adalah merupakan perikatan. Perikatan timbul disamping berdasarkan perjanjian, perjanjian juga dapat timbul karena undang-undang atau bersumber pada undang-undang. Menurut penulis, salah satu perikatan yang bersumber pada undang-undang ini adalah pembentukan PPPSRS. Khusus pada kasus MIM, undangundang mewajibkan kepada konsemen dalam hal ini penghuni satuan rumah susun untuk membentuk PPPSRS tetapi juga mewajibkan pelaku pembangunan/pelaku usaha untuk mengelola memfailitasi pembentukannya. Pelaku pembangunan/ pelaku usaha hanya diberikan waktu pengelolaan ruamah susun smpai masa transisi, kenyataan yang ada adalah pelaku usaha/pelaku pembangunan sampai masa transisi itu berakhir masih juga mengelolaannya

Terkait dengan perlindungan konsomen, maka harus diperhatikannkan juga UU No. 8 Tahun 1999 tentang perlindungan konsumen (UUPK). "Perlindungan konsumen" adalah segala upaya yang menjamin adanya kepastian hukum untuk memberi perlindungan kepada konsumen. (Pasal 1 angka 1 UUPK). "Perlindungan hukum" adalah suatu pemberian jaminan atau kepastian bahwa seseorang akan mendapatkan apa yang telah menjadi hak dan kewajibannya, sehingga yang bersangkutan merasa aman.
Perlindungan hukum UUPK diberikan kepada setiap konsumen. Konsumen berdasarkan Pasal 2 UUPK angka 2 adalah: Konsumen adalah setiap pemakai barang dan/atau jasa yang tersedia dalam masyarakat, baik bagi kepentingan diri sendiri, keluarga, orang lain maupun makhluk hidup lain dan tidak untuk diperdagangkan.

Konsumen pada rumah susun adalah masyarakat yang membeli barang berupa sarutan rumah susun yang beli pada pelaku pembangunan/pelaku usaha dan juga penghuni. Penghuni adalah orang yang menempati sarusun, baik sebagai pemilik maupun bukan pemilik.pembentukan UUPK adalah:

1. meningkatkan kesadaran, kemampuan dan kemandirian konsumen untuk melindungi diri;

2. mengangkat harkat dan martabat konsumen dengan cara menghindarkannya dari ekses negatif pemakaian barang dan/atau jasa;

3. meningkatkan pemberdayaan konsumen dalam memilih, menentukan, dan menuntut hakhaknya sebagai konsumen;

4. menciptakan sistem perlindungan konsumen yang mengandung unsur kepastian hukum dan keterbukaan informasi serta akses untuk mendapatkan informasi;

5. menumbuhkan kesadaran pelaku usaha mengenai pentingnya perlindungan konsumen sehingga tumbuh sikap yang jujur dan bertanggung jawab dalam berusaha;

6. meningkatkan kualitas barang dan/ atau jasa yang, menjamin kelangsungan usaha produksi barang dan/atau jasa, 
kesehatan, kenyamanan, keamanan, dan keselamatan konsumen.

Konsumen pada satuan rumah susun juga seharus menjadi terget UUPK. Hal ini disebabkan karena penghuni dan pemilik membeli barang atau menyewa barang yang diproduksi oleh pelaku usaha/pelaku pembangunan. Konsumen rumah susun juga seharusnya menjadi tujuan dari UUPK karena sebagai konsumen penghuni dan pemilik belum memiliki kesadaran dan kemampuan untuk melindungi diri. Disamping itu konsumen tidak mengetahui hukum yang mengatur mengenai barang atau rumah susun yang dibelinya. Ketidaktahuan itu juga dimanfaatkan oleh pelaku pembangunan/pelaku usaha.

Konsumen dalam UUPK memiliki hak dan kewajiban yaitu:

Hak konsumen adalah:

1. hak atas kenyamanan, keamanan dan keselamatan dalam mengkonsurnsi barang dan/atau jasa;

2. hak untuk memilih barang dan/atau jasa serta mendapatkan barang dan/ atau jasa tersebut sesuai dengan nilai tukar dan kondisi serta jaminan yang dijanjikan;

3. hak atas informasi yang benar, jelas, dan jujur mengenai kondisi dan jaminan barang dan/atau jasa;

4. hak untuk didengar pendapat dan keluhannya atas barang dan/atau jasa yang digunakan;

5. hak untuk mendapatkan advokasi, perlindungan, dan upaya penyelesaian sengketa perlindungan konsumen secara patut;

6. hak untuk mendapat pembinaan dan pendidikan konsumen;
7. hak untuk diperlakukan atau dilayani secara benar dan jujur serta tidak diskriminatif;

8. hak untuk mendapatkan komnpensasi, ganti rugi dan/atau penggantian, apabila barang dan/atau jasa yang diterima tidak sesuai dengan perjanjian atau tidak sebagaimana mestinya;

9. hak-hak yang diatur dalam ketentuan peraturan perundang-undangan lainnya.

Kewajiban konsumen adalah:

1. membaca atau mengikuti petunjuk informasi dan prosedur pemakaian atau pemanfaatan barang dan/atau jasa, demi keamanan dan keselamatan;

2. beritikad baik dalam melakukan transaksi pembelian barang dan/atau jasa;

3. membayar sesuai dengan nilai tukar yang disepakati;

4. mengikuti upaya penyelesaian hukum sengketa perlindungan konsumen secara patut.

Pada konsumen rumah susun salah satu hak yang terdapat di UUPK tidak didapatkannnya yaitu hak atas informasi yang benar, jelas, dan jujur mengenai kondisi dan jaminan barang dan/atau jasa.

Pembentukan PPPSRS berdasarkan Undang-undang No 20 Tahun 2011 Tentang Rumah Susun. Pembentukan PPPSRS ini sebagai salah satu perlindungan bagi penghuni dan pemilik satuan rumah susun. Tetapi tentu saja pembentukannnya harus sesuai dengan undang-undang yaitu yaitu harus definitif (berbadan hukum). Beberapa pasal berkaitan dengan PPPSRS adalah: 


\section{Pasal 59}

- Ayat 1 : Pelaku pembangunan yang membangun Rumah Susun dalam masa transisi sebelum terbentuknya PPPSRS wajib mengelola Rumah Susun.

- Ayat 2 : Masa transisi sebagaimana dimaksud pada ayat 1 ditetapkan paling lama satu tahun sejak penyerahan pertama kali Sarusun Kepada pemilik.

\section{Pasal 74}

- $\quad$ Ayat 1 : Pemilik wajib membentuk PPPSRS. Artinya yang wajib membentuk PPPSRS hanyalah para pemilik, berdasarkan hak suara yang dimiliki. Dalam Rapat Umum Pembentukan PPPSRS para pemilik berhak memberikan suara dalam voting, satu nama satu suara.

- $\quad$ Ayat 2: PPPSRS sebagaimana yang dimaksud ayat 1 beranggotakan Pemilih dan Penghuni yang mendapatkan surat kuasa dari Pemilik.

\section{Penjelasannya:}

Kuasa Pemilik kepada Penghuni terbatas pada HAL PENGHUNIAN. Misalnya dalam hal penentuan besarnya iuran untuk keamanan, kebersihan atau sosial kemasyarakatan.

\section{Pasal 77}

- (2)Dalam hal PPPSRS memutuskan sesuatu yang berkaitan dengan kepentingan penghunian ruma susun, setiap anggota berhak memberikan satu suara.

Penjelasan Ayat 2 yang dimaksud dengan setiap anggota memberikan satu suara adalah apabila Sarusun telah dihuni, suara Pemilik dapat dikuasakan kepada setiap Penghuni Sarusun. Apabila Sarusun belum dihuni setiap Nama Pemilik hanya mempunyai satu hak suara walaupun pemilik bersangkutan memiliki lebih dari satu Sarusun.

Bila pelaku pembangunan masih memiliki unit Sarusun yang belum terjual maka secara otomatis berlaku sebagai pemilik dengan satu hak suara. Dia juga dapat memberikan hak suara dalam voting pembentukan PPPSRS dan pemilihan pengurus PPPSRS, apabila yang datang ikut rapat adalah Direktur Perseroan. Bisa juga Perseroan memberikan Surat Kuasa Kepada orang lain, dan ia akan memiliki satu suara dalam voting.

Hukum yang dijelaskan diatas, para Pemilik telah cukup memiliki senjata Hukum untuk membentuk PPPSRS dan memilih Pengurus PPPSRS diantara para pemilik. Sehingga inilah satu-satunya pembentukan PPPSRS yang sah menurut Hukum. Direktur Perseroan pelaku pembangunan berhakmemilih dengan satu suara dan berhak dipilih sebagai Pengurus PPPSRS apabila dia menghuni Sarusun itu. Tetapi karyawan lainnya, dia hanya bisa hadir sebagai Pemegang kuasa bila ia juga menghuni, tetapi tidak memiliki hak suara dalam voting pembentukan PPPSRS maupun pemilihan pengurus PPPSRS. Tetapi apabila tidak menghuni sama sekali berarti tidak punya hak suara sebagai pemilik ataupun sebagai Pemegang Surat kuasa. Yang punya hak memilih dan dipilih hanyalah Pemilik yang menghuni.

Sangat jelas bahwa pelaku pembangunan, walaupun didukung 
seluruh karyawannya secara Hukum tidak berhak membentuk PPPSRS atau menguasai kursi Pengurus PPPSRS. Bagaimana mungkin, hanya memiliki satu hak suara dalam voting Pembentukan PPPSRS atau pemilihan Pengurus PPPSRS. Kenyataannya sampai sekarang pelaku pembangunan membentuk PPPSRS dan menempatkan karyawannya sebagai Pengurus. Jelaslah itu merupakan pelanggaran Hukum yang telah dijelaskan diatas. Juga PPPSRS cacat Hukum yang telah dibentuk itu telah berserikat didalam PPPSRS. Pentingnya pembentukan PPPSRS ini sehingga perlu di dorong pembentukkannya sehingga wajar bila UU No. 20 Tahun 2011 memberikana pernyataan agar pelaku pembangunan/ pelaku usaha memberikan fasilitas untuk pembentukan PPPSRS.

Pembentukan PPPSRS di MIM Bandung belum terbentuk disebabkan beberapa kendala yang telah disebutkan di atas. Sehingga proses pembentukan juga belum dilaksanakan proses tersebut dapat kita lihat padaPeraturan Menteri Negara Perumahan Rakyat Nomor 15/ PERMEN/M/2007 ini dapat dilihat proses atau tahapan pembentukan PPSRS pada Pasal 4, yaitu:

1. Sosialisasi kepenghunian

Sosialisasi kepenghunian wajib dilakukan oleh pelaku pembangunan termasuk pengelolaan rusunami, serta hak dan kewajiban penghuni dalam pembentukan PPSRS. Sosialisasi kepenghunian dilakukan pada saat sarusun milik mulai dipasarkan kepada calon pemilik. Pelaksanaan sosialisasi kepenghunian oleh pelaku pembangunan dapat melibatkan organisasi sosial kemasyarakatan atau organisasi profesional. MIM belum melaksanakan sekalipun mengenai sosialisasi ini sehingga wajar jika para penghuni dan pemilik belum juga mengetahui kewajiban serta hakhaknya yang didasrkan pada undangundang.

2. Pendataan pemilik dan/atau penghuni Pendapatan penghuni atas sarusun milik dilakukan oleh pelaku pembangunan sesuai prinsip kepenghunian yang sah. Syarat keanggotaan adalah surat tanda bukti kepemilikan saurusun milik. Pendataan penghuni harus diperbaharui sekurang-kurangnya tiap 6 (enam) bulan. Pendataan penghuni disusun oleh pelaku pembangunan dijadikan sebagai dasar penyelenggaraan musyawarah penghuni. Data kepemilikan satuan rumah susun hanya ada pada badan pengelola saat ini dan data tersebut tidak dapat diakses oleh pemilik dan penghuni lainnya.

3. Pembentukan panitia musyawarah Pelaku pembangunan memfasilitasi penyelenggaraan pembentukan panitia musyawarah dan diselenggarakan maksimal 1 (satu) tahun sejak penyerahaan sarusun milik yang pertama.

Biaya penyelenggaraan pembentukan panitia musyawarah yang pertama kali dibebankan kepada pelaku pembangunan.

4. Tugas panitia musyawarah

Panitia musyawarah bertugas menyelenggarakan musyawarah dan bertanggung jawab kepada pemilik 
dan/atau penghuni dan panitia musyawarah sekurang-kurangnya harus terdiri dari ketua, sekretaris, dan bendahara. Susunan panitia musyawarah dapt dilengkapi dengan seksi-seksi dan staff/anggota seksi sesuai kebutuhan.

5. Kegiatan panitia musyawarah

Panitia musyawarah menyelenggarakan kegiatan-kegiatan untuk membahas dan menyiapkan:
a. Materi naskah-naskah yang akan dibahas dan diputuskan dalam musyawarah.
b. Rancangan keputusan-keputusan musyawarah.
c. Kegiatan teknis penyelenggaraan musyawarah.

Dari uraian di atas jelas pemilik dan penghuni sama sekali tidak mampu untuk membentuk PPPSRS karena keterbatasan dan ketidaktahuan akan hukum yang berlaku. Pemilik dan penghuni perlu melakukan perjuangan lebih untuk melindungi hak mereka atas kepemilikan satuan rumah susun. Pemilik dan/atau penghuni satuan rumah susun mempunyai hak dan kewajiban yang diatur oleh Peraturan Pemerintah No. 4 Tahun 1988 tentang Rumah Susun. Seperti yang tercantum dalam pasal di bawah ini.

Pasal 61 PP No. 4 Tahun 1988,

Ayat (1) setiap penghuni berhak:

1. memanfaatkan rumah susun dan lingkungannya termasuk bagian bersama, benda bersama, dan tanah bersama secara aman dan tertib;

2. mendapatkan perlindungan sesuai dengan Anggaran Dasar dan Anggaran Rumah Tangga;
3. memilih dan dipilih menjadi Anggota Pengurus Perhimpunan Penghuni. Ayat (2) setiap penghuni berkewajiban:

1. mematuhi dan melaksanakan peraturan tata tertib dalam suatu rumah susun dan lingkungannya sesuai dengan Anggaran Dasar dan Anggaran Rumah Tangga;

2. membayar iuran pengelolaan dan premi asuransi kebakaran;

3. memelihara rumah susun dan lingkungannya termasuk bagian bersama, benda bersama, dan tanah bersama.

Ayat (3) setiap penghuni dilarang:

1. melakukan perbuatan yang membahayakan keamanan, ketertiban, dan keselamatan terhadap penghuni lain, bangunan dan lingkungannya;

2. mengubah bentuk dan/atau menambah bangunan di luar satuan rumah susun yang dimiliki tanpa mendapat persetujuan perhimpunan penghuni.

Selain hak yang diatur dalam pasal di atas, penghuni yang juga merupakan anggota Perhimpunan Penghuni Rumah Susun juga mempunyai hak suara. Penghuni dapat mengunakan hak suara ini dalam kegiatan rapat umum anggota perhimpunan penghuni. Hak suara ini terbagi dalam dalam tiga (3) kategori, yaitu:

1. Hak Suara Penghunian, yaitu hak suara para anggota PPRS untuk menentukan hal-hal yang menyangkut tata tertib, pemakaian fasilitas, dan kewajiban pembayaran iuran atas pengelolaan dan asuransi kebakaran terhadap hak bersama seperti bagian bersama, benda bersama dan tanah bersama. 
Setiap pemilik hak atas tanah satuan rumah susun diwakili oleh satu suara.

2. Hak Suara Pengelolaan, yaitu hak suara para anggota PPRS untuk menentukan hal-hal yang menyangkut pemeliharaan, perbaikan dan pembangunan prasarana lingkungan, serta fasilitas sosial, bagian bersama, benda bersama dan tanah bersama. Hak Suara Pengelolaan dihitung berdasarkan nilai perbandingan proporsional dari setiap satuan rumah susun.

3. Hak Suara Pemilikan, yaitu hak suara para anggota PPRS untuk menentukan hal-hal yang menyangkut hubungan antar sesama penghuni satuan rumah susun; Pemilihan Pengurus PP; dan biaya-biaya atas satuan rumah susun. Hak Suara Pemilikan dihitung berdasarkan nilai perbandingan proporsional dari setiap satuan rumah susun.

\section{PENUTUP}

Berdasarkan uraian pada babbab sebelumnya, maka dapat ditarik kesimpulan antara lain:

1. Ketentuan yang berlaku yang berkaitan dengan rumah susun diantaranya adalah UU No. 20 Tahun 2011 tentang Rumah Susun, Peraturan Pemerintah Nomor 4 Tahun 1988 tentang Rumah Susun, Keputusan Menteri Negara Perumahan Rakyat Nomor: 06/KPTS/ BKP4N/1995 tentang Pedoman Pembuatan Akta Pendirian, Anggaran Dasar dan Anggaran Rumah Tangga Perhimpunan Penghuni Rumah Susun, Peraturan Menteri Negara Perumahan Rakyat Nomor 15/PERMEN/M/2007 tentang Tata Laksana Pembentukan Perhimpunan Penghuni Rumah Susun Sederhana Milik. Disamping itu juga berlaku Kitab Undang-Undang Hukum Perdata berkaitan dengan perjanjian yang dibuat, UU No. 8 Tahun 1999 tentang Perlindungan Konsumen.

2. Perlindungan bagi pemilik dan penghuni satuan rumah susun di Kota Bandung ternyata sampai saat ini masih belum terlindung terbukti dengan tidak adanya peraturan setaraf tingkat peraturan walikota yang mampu memberikan kepastian hukum, bila dikaitkan dengan peraturan mengenai prlindungan konsumen juga ternyata belum melindungi karena perlindungan konsumen lebih condong pada hukum pidana dibanding dengan hukum perdata.

\section{DAFTAR PUSTAKA}

Adrian Sutedi, Hukum Rumah Susun \& Apartemen, Sinar Grafika, Jakarta, 2012.

Achmad Rustandi, Ibrahim Bachtiar, Pengantar Teori Hukum, Multi Karya Ilmu, Bandung, 1983.

Andasasmita, Komar, Notaris II Contoh Akta Otentik dan Penjelasannya, Ikatan Notaris Indonesia Daerah Jawa Barat, Bandung, Tahun 1990.

$\longrightarrow$ Hukum Apartemen, Rumah Susun Cetakan Kedua, Ikatan Notaris Indonesia Komisariat Daerah Jawa Barat, Bandung, Tahun 1986. 
Alif, M. Rizal, Analisis Kepemilikan Hak Atas Tanah Satuan Rumah Susun di Dalam Kerangka Hukum Benda, CV. Nuansa Aulia, Bandung, Tahun 2009.

Boedi Harsono, Berbagi Masalah Hukum Bersangkutan dengan Rumah Susun dan Pemilikan Satuan Rumah Susun, Majalah Hukum dan Pembangunan Desember 1986.

Badrulzaman, Mariam Darus, KUH Perdata Buku III Hukum Perikatan Dengan Penjelasan, Alumni, Bandung, Tahun 1996.

Gunawan Widjaja, Hukum tentang Perlindungan Konsumen, Jakarta, Gramedia, Pustaka Utama.

Harjono, Perlindungan Hukum terhadap Konsumen yang Menderita Kerugian dalam transaksi Properti Menurut Undang-Undang Perlindungan Konsumen (Studi Pengembangan Perumahan PT Fajar Bangun Raharja Surakarta), Yustisia, Edisi Nomor 68 Mei-Agustus 2006.

Imam Koeswahyono, Hukum Rumah Susun: Suatu Bekal Pengantar Pemahaman, Bayumedia, Malang, 2004. 